\title{
Current Groundwater Conditions in Alluvial Gangetic Plains of Haridwar District, Uttarakhand, India
}

\author{
GOPAL KRISHAN ${ }^{1}$, SURJEET SINGH ${ }^{1}$, \\ ANURAG KHANNA ${ }^{2}$, R.P. SINGH ${ }^{1}$ and N.C. GHOSH ${ }^{1}$ \\ ${ }^{1}$ National Institute of Hydrology, Roorkee, Uttarakhand, India. \\ ${ }^{2} \mathrm{CGWB}$, Dehradun, India.
}

http://dx.doi.org/10.12944/CWE.11.3.07

(Received: October 12, 2016; Accepted: October 29, 2016)

\begin{abstract}
In the present study, data of 41 hydrograph stations distributed in the Haridwar district are analysed for the years 2014-15 for depth to water level and water quality. The average depth to water level during pre-monsoon is found $10.74 \mathrm{~m}$ and in post-monsoon there is a rise of $0.23 \mathrm{~m}$ in average water level and found $10.51 \mathrm{~m}$. Among all the 6 blocks viz. Bhagwanpur, Bhadarabad, Khanpur, Laksar, Narsan and Roorkee, the distribution of water level shows that the water levels are deep in the entire Bhagwanpur block. For assessing the groundwater quality, the water samples were collected from 40 sites covering the entire district. The groundwater is formed as $\mathrm{Ca}-\mathrm{Mg}-\mathrm{HCO}_{3}$ type. In the groundwater, alkaline earths exceed the alkalis and weak acids dominate strong acids. Although groundwater quality is good for drinking as well as irrigation purpose but in few samples higher concentrations of $\mathrm{NO}_{3}^{-}, \mathrm{Cl}^{\prime \prime}$ and $\mathrm{SO}_{4}{ }^{2 "}$ ions are found and hence continuous monitoring is required for these ions as precautionary measures.
\end{abstract}

Keywords: Groundwater, depth to water level, water quality, Haridwar, Indo-Gangetic basin.

\section{INTRODUCTION}

Increasing demand of good quality water across all sectors has put an enormous pressure on groundwater an ubiquitous source of high-quality fresh water ${ }^{1}$ which has resulted in its continuous depletion and quality deterioration in Indo-gangetic plains $^{2-15}$. Indo-gangetic basin is one of the major aquifer systems of the World ${ }^{1}$ and southern component of Haridwar district in Uttarakhand forms the part of alluvial Indo-Gangetic plains. Upper Ganga Canal passing through the district has a wide network of distributaries and minors are making surface irrigation prominent in Bahadrabad, Roorkee and Narsan blocks. Khanpur and Laksar blocks fall in the south-east part of the district forms part of Khadars of Ganga and Solani rivers. There is no canal irrigation in the Bhagwanpur block.
The district has many industries generating considerable toxic effluents which might contaminate the groundwater of the district in future. Groundwater quality of Haridwar district shows high concentrations of $\mathrm{NO}_{3}{ }^{-}, \mathrm{Cl}^{\prime \prime}$ and $\mathrm{SO}_{4}{ }^{2 "}$ that are generally due to the input from anthropogenic activities, which are local in nature ${ }^{16}$. Overall groundwater quality class of Haridwar district is fair and needs filtration and disinfectant ${ }^{17-18}$ computed using standard methodology ${ }^{19}$. Keeping this in view, the present work was carried out to assess the current groundwater conditions in terms of depth to water level and groundwater quality for finding its suitability for drinking and irrigation purpose in the Haridwar district, Uttarakhand State, India.

\section{Study area}

Haridwar district lies between $29^{\circ} 33^{\prime}$ $30^{\circ} 14^{\prime} \mathrm{N}$ latitude and $77^{\circ} 57^{\prime}-78^{\circ} 1^{\prime} \mathrm{E}$ longitude at 
an average altitude of $230 \mathrm{~m}$. District Haridwar is the most densely populated district of Uttarakhand having a population of 19,29,029 (Census, 2011) ${ }^{20}$. Haridwar district has a total geographical area of $2960 \mathrm{~km}^{2}$ comprising of 6 administrative blocks viz. Roorkee, Bahadrabad, Narsan, Khanpur, Laksar and Bhagwanpur (Fig. 1). Haridwar district has an average temperature of $22^{\circ} \mathrm{C}$, relative humidity ranging from $37-88 \%$ and normal rainfall is 1134 $\mathrm{mm}$ with $80 \%$ of rainfall occurring during the monsoon season (June-September). The district is characterized under Indo-Gangetic alluvium group of soils and is represented predominately by loamy soils. The stage of groundwater development is $65 \%$ and 3 blocks namely Bhagwanpur, Khanpur and Laksar are categorized under 'semi-critical' condition.

\section{Methodology}

Depth to water level is important as it determines the distance that contaminants have to travel before reaching to the groundwater. In Haridwar district, depth to water level was measured at Central Ground Water Board (CGWB) monitoring sites at 41 locations during the year 2014-15. For assessing the groundwater quality, the water samples were collected during the year 2013-14 from 40 sites covering the entire district as shown in Fig. 2. The sample were analysed by CGWB, Dehradun using the standard procedure described by APHA $(2012)^{21}$.

\section{RESULTS AND DISCUSSION}

\section{Depth to water level}

Depth to water level collected both for premonsoon and post monsoon seasons during 201415 are presented in Fig. 3 and 4, respectively.

The data of 41 hydrograph stations distributed over the entire district are analysed for the years 2014-2015. The depth to water level during pre-monsoon ranged from 1.96-69.30 m with an average of $10.74 \mathrm{~m}$ and in post-monsoon it ranged from 1.57-52.20 $\mathrm{m}$ with an average of 10.51 $\mathrm{m}$ showing an increase on $0.23 \mathrm{~m}$ in average water

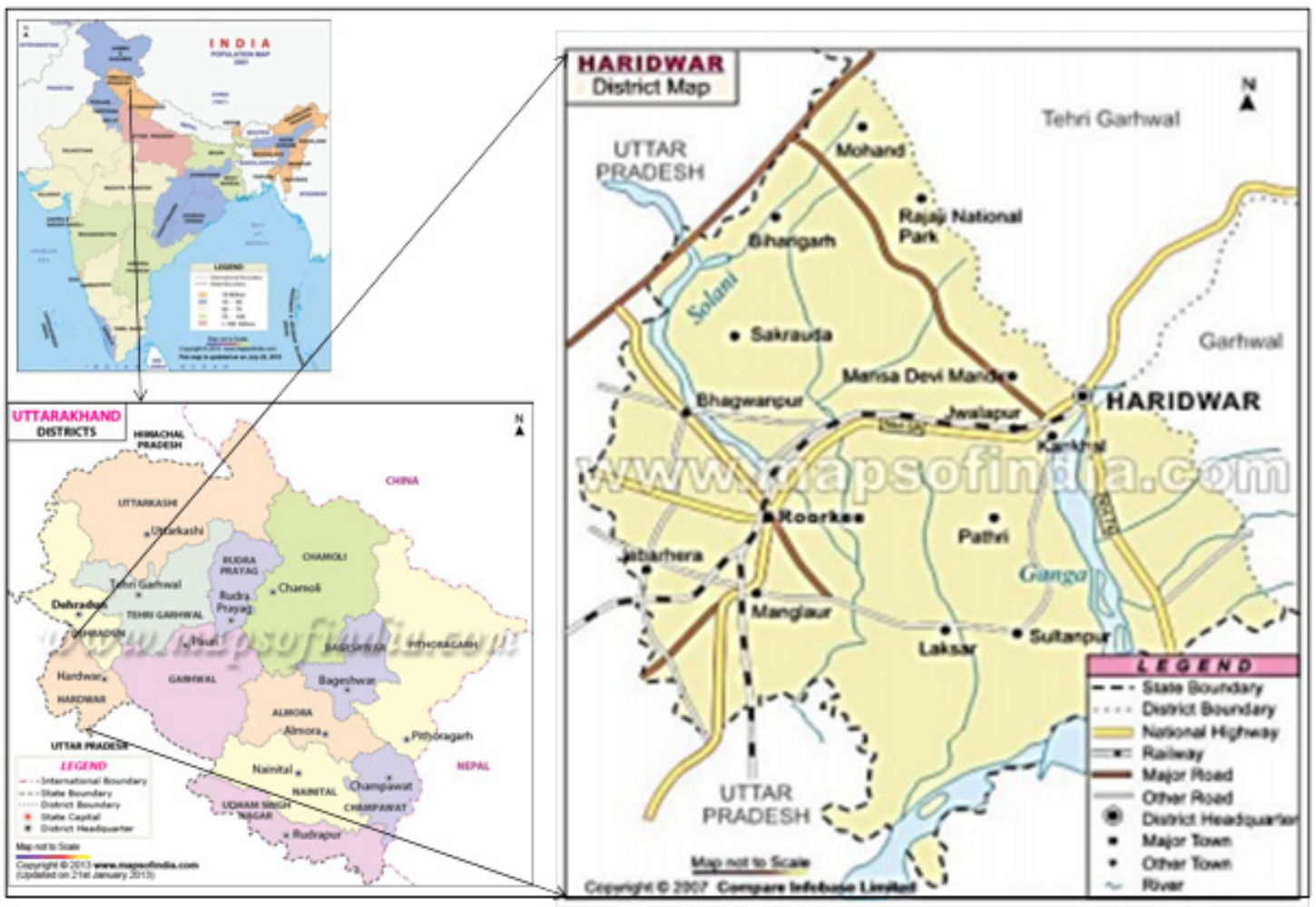

Fig. 1: Location map of study area 
level. In Bhabhar formation, depth to water level ranges from $10.91 \mathrm{~m}$ to $69.30 \mathrm{~m}$ whereas in the Gangetic alluvium it ranged from $2.50 \mathrm{~m}$ to $22.69 \mathrm{~m}$. The distribution of water level shows that the water levels are deep in entire Bhagwanpur block.

\section{Groundwater quality}

The statistical summary of the water quality parameters is given in Table 1 . The average value of $\mathrm{pH}$ was measured 8 and the groundwater

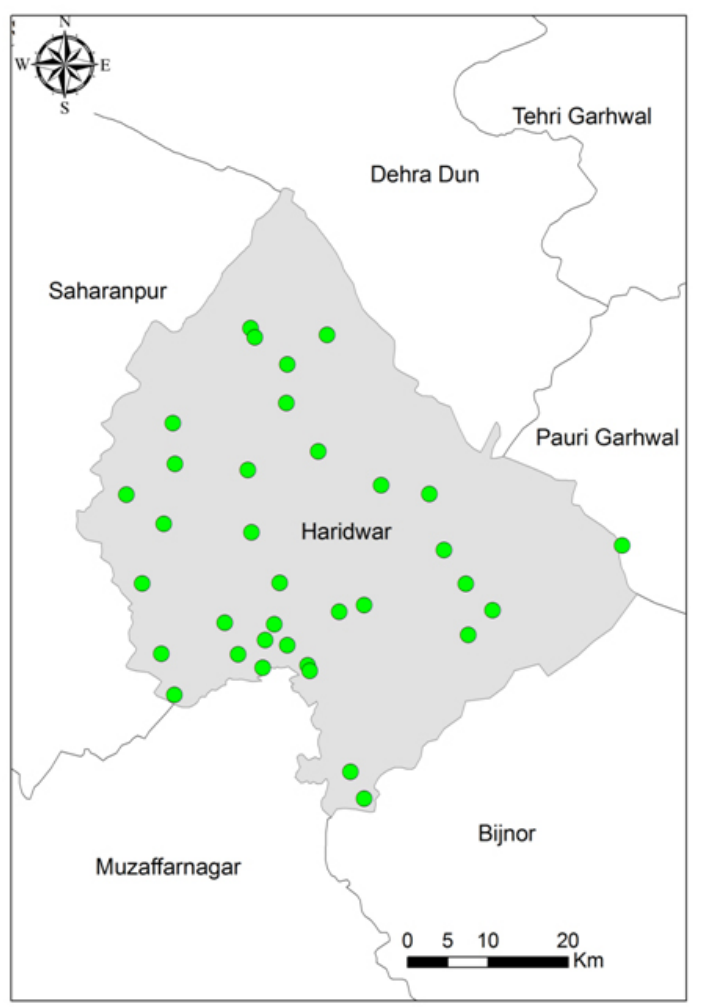

Fig. 2: Sampling points in Haridwar district, Uttarakhand was slightly alkaline in nature, EC of groundwater varies from 262 to $1535 \mu \mathrm{S} / \mathrm{cm}$ with an average of $656 \mu \mathrm{S} / \mathrm{cm}$. $\mathrm{Ca}^{++}$ions concentration ranged from 28-108 $\mathrm{mg} / \mathrm{l}$ with an average of $62 \mathrm{mg} / \mathrm{l}$; $\mathrm{Mg}^{++}$ions concentration ranged from $7-95 \mathrm{mg} / \mathrm{l}$ with an average $29 \mathrm{mg} / \mathrm{l} ; \mathrm{Na}^{+}$ranged from $5-92 \mathrm{mg} / \mathrm{l}$ with an average $33 \mathrm{mg} / \mathrm{l} ; \mathrm{K}^{+}$ions concentration ranged from 0.5-119 $\mathrm{mg} / \mathrm{l}$ with an average $33 \mathrm{mg} / \mathrm{l}$. $\mathrm{Ca}^{2+}$ and $\mathrm{Mg}^{2+}$ are the dominant cations contributing to $67 \%$ of the total cation contribution, while $\mathrm{Na}^{+}$and $\mathrm{K}^{+}$contribute about $33 \%$. All the cations are found within the permissible limit of BIS: 10500-2012. Calcium in water is found to arise mostly from the dissolution of $\mathrm{Ca}^{++}$bearing minerals of the aquifer formation and often it is the most abundant cation in aquatic water. Weathering and dissolution of calcium carbonate (limestone and dolomite) and calc-silicate minerals (amphiboles, pyroxenes, olivine, biotite etc) are the most common sources of calcium in aquatic system.

$\mathrm{NO}_{3}{ }^{-}$ions concentration ranged from 0.1 $86 \mathrm{mg} / \mathrm{l}$ with an average $15.6 \mathrm{mg} / \mathrm{l}$ and sample at Libraheri was found above permissible limit of 45 $\mathrm{mg} / \mathrm{l}$. $\mathrm{HCO}_{3}-$ ions concentration ranged from 128$494 \mathrm{mg} / \mathrm{l}$ with an average $326 \mathrm{mg} / \mathrm{l}$. The $\mathrm{SO}_{4}-$ ions concentration ranged from $2.5-310 \mathrm{mg} / \mathrm{l}$ with an average $36 \mathrm{mg} / \mathrm{l}$; $\mathrm{Cl}^{-}$ranged from $4-128 \mathrm{mg} / \mathrm{l}$ with an average $29 \mathrm{mg} / \mathrm{l}$. Among anions, $\mathrm{HCO}_{3}$ - contributed $81 \%$ of total and the other anions had a contribution of $19 \%$. Higher $\mathrm{HCO}_{3}$ " concentration is indicative of carbonate weathering and decomposition of organic matter. Northern part of district forms recharge zone for the gangetic plain aquifers. Sub-surface water moves through the boulders predominantly of which are transported from the Karol belt which have carbonate minerals.

Table 1: Statistical summary of analyzed water quality parameters in Haridwar district, Uttarakhand $(n=41)$

\begin{tabular}{|c|c|c|c|c|c|c|c|c|c|c|c|}
\hline Parameters & $\mathrm{pH}$ & $\begin{array}{c}(\mu \mathrm{S} / \mathrm{cm}) \\
\mathrm{EC}\end{array}$ & $\mathbf{F}^{-}$ & $\mathrm{Cl}^{-}$ & $\mathrm{HCO}_{3}^{-}$ & $\mathrm{SO}_{4}{ }^{2-}$ & $\begin{array}{l}\mathrm{mg} / \mathrm{l} \\
\mathrm{NO}_{3}^{-}\end{array}$ & $\mathrm{Ca}^{2+}$ & $\mathrm{Mg}^{2+}$ & $\mathrm{Na}^{+}$ & $\mathbf{K}^{+}$ \\
\hline Min & 7.7 & 262 & 0.0 & 3.5 & 128 & 2.5 & 0.1 & 28 & 7.3 & 5 & 0.5 \\
\hline Max & 8.2 & 1535 & 0.5 & 128.0 & 494 & 310.0 & 86.0 & 108 & 95.0 & 92 & 119.0 \\
\hline Avg. & 8.0 & 656 & 0.2 & 29.2 & 326 & 36.4 & 15.6 & 62 & 28.5 & 33 & 11.7 \\
\hline S. D. & 0.2 & 260 & 0.1 & 33.6 & 70 & 54.7 & 19.0 & 18 & 16.4 & 26.6 & 25.1 \\
\hline $\begin{array}{l}\text { Permissible } \\
\text { limit }\end{array}$ & $6.5-8.5$ & - & 1.5 & 1000 & - & 400 & 45 & 200 & 100 & 200 & - \\
\hline
\end{tabular}




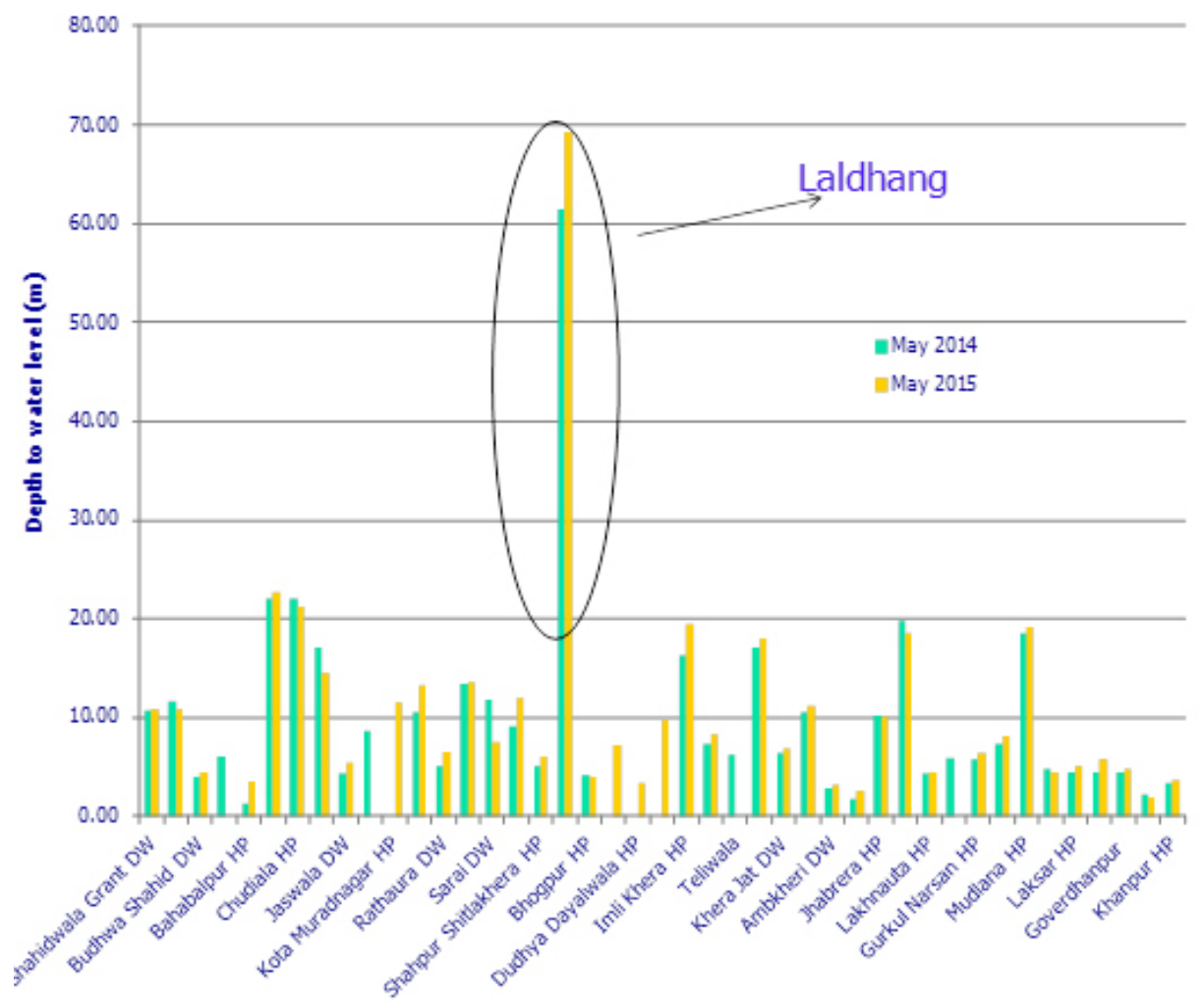

Fig. 3: Groundwater level fluctuations in Haridwar district during 2014-15

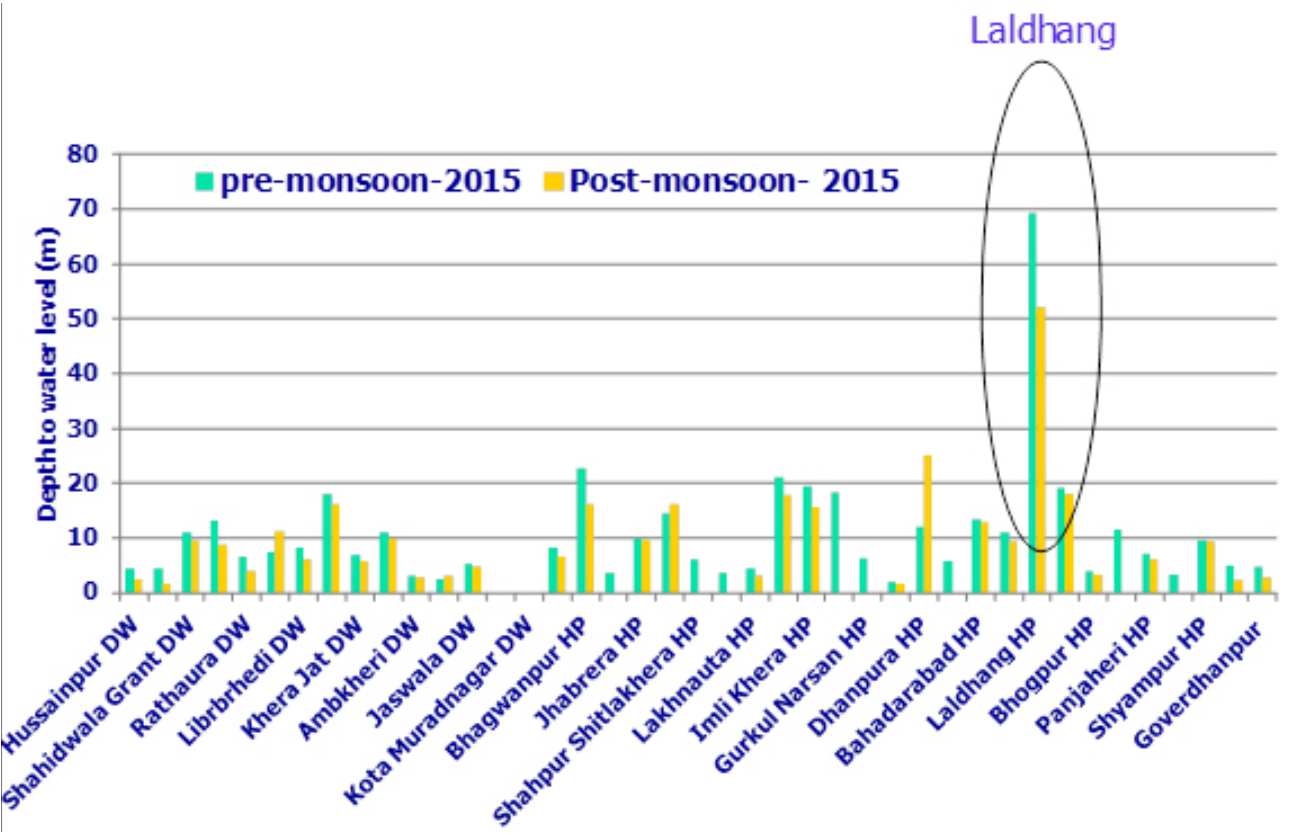

Fig. 4: Groundwater level fluctuations during pre-monsson and post-monsoon in Haridwar district in the year 2015 
The groundwater type is of $\mathrm{Ca}-\mathrm{Mg}-\mathrm{HCO}_{3}$. In the groundwater, the alkaline earths exceed the alkalis and weak acids dominate strong acids. The higher concentrations of $\mathrm{NO}_{3}{ }^{-}, \mathrm{Cl}^{\prime \prime}$ and $\mathrm{SO}_{4}{ }^{2 "}$ are generally due to the input from anthropogenic activities, which are local in nature.

\section{CONCLUSIONS}

Stage of groundwater development is approximately $65 \%$ for the entire Haridwar district and presently falls under safe category. Three blocks namely Bhagwanpur, Khanpur and Laksar are categorized under 'semi-critical'. Although groundwater quality is good for drinking as well as irrigation purpose but in few samples higher concentrations of $\mathrm{NO}_{3} ; \mathrm{Cl}^{\prime \prime}$ and $\mathrm{SO}_{4}{ }^{2 "}$ ions are found and hence continuous monitoring is required for these ions as precautionary measures. Calcium in water arising mostly from dissolution of $\mathrm{Ca}^{++}$ bearing minerals of the aquifer formation and often it is the most abundant cation in aquatic water. Weathering and dissolution of calcium carbonate (limestone and dolomite) and calc-silicate minerals (amphiboles, pyroxenes, olivine, biotite etc) are the most common sources of calcium in aquatic system. Northern part of district forms recharge zone for the gangetic plain aquifers. Sub-surface water moves through the boulders predominantly of which are transported from the Karol belt which have carbonate minerals. Since the area is agriculture dominated and industries are also developing therefore, integrated water resource development and management framework is required to be adopted along with creation of shareable information which is essential for sustainable use of water resources.

\section{ACKNOWLEDGEMENTS}

Authors thank Director, National Institute of Hydrology, Roorkee for all the support and encouragement.

\section{REFERENCES}

1. Taylor, R.G. et al. Groundwater and climate change. Nature Climate Change 3:322-329. (2013).

2. Chopra, R.P.S. and Krishan, Gopal. Analysis of aquifer characteristics and groundwater quality in southwest Punjab, India. Journal of Earth Science and Engineering. 4(10): 597604. (2014).

3. Chopra, R.P.S. and Krishan, Gopal. Assessment of groundwater quality in Punjab. Journal of Earth Science and Climate Change. 5(10):243. (2014).

4. Krishan, Gopal, Rao, M.S., Loyal, R.S., Lohani, A.K., Tuli, N.K., Takshi, K.S., Kumar, C.P., Semwal, P and Kumar Sandeep. Groundwater level analyses of Punjab, India: A quantitative approach. Octa Journal of Environmental Research. 2(3): 221-226. (2014).

5. Krishan Gopal, Lapworth D. J., Rao M. S., Kumar C. P., Smilovic M. and Semwal P. Natural (Baseline) Groundwater Quality In The Bist-Doab Catchment, Punjab, India: A Pilot Study Comparing Shallow and Deep Aquifers. International Journal of Earth
Sciences and Engineering, 7 (01): 16-26. (2014).

6. Krishan, G., Rao, M. S., Purushothaman, P., Rawat, Y. S., Kumar, C.P., Gupta, S., Bhatia, A.K., Marwah, S., Kaushik, Y.B., Angurala, M.P. and Singh, G.P. Groundwater Resources in Bist-Doab Region, Punjab, India-an overview. NDC-WWC Journal. 3(2): 5-13. (2014).

7. Krishan, Gopal, Lohani, A.K., Rao, M.S. and Kumar, C.P. Prioritization of groundwater monitoring sites using cross-correlation analysis. NDC-WWC Journal, 3(1): 28-31. (2014).

8. Lapworth DJ, MacDonald AM, Krishan G, Rao MS, Gooddy DC, Darling WG. Groundwater recharge and age-depth profiles of intensively exploited groundwater resources in northwest India. Geophys. Res. Lett., 42(18): 7554-7562. (2015).

9. Lapworth, D.J., Krishan, G., Macdonald, A.M., Rao, M.S., Gooddy, D.C. \& Darling, W.G. Using Environmental Tracers to Understand the Response of Groundwater Resources in Nw India to Sustained Abstraction. In Proc. 
of 41st International Conf. of International Association of Hydro-geologist (IAH-2014) on Groundwater: Challenges and Strategies during Sep. 18-19, 2014. at Marrakech Morocco. (2014).

10. MacDonald, Alan, Bonsor, Helen, Ahmed, Kazi, Burgess, William, Basharat, Muhammad, Calow, Roger, Dixit, Ajaya, Foster, Stephen, Krishan, Gopal , Lapworth, Daniel , Lark, Murray, Moench, Marcus, Mukherjee, Abhijit, Rao, M.S., Shamsudduha, Mohammad, Smith, Linda, Taylor, Richard, Tucker, Josephine, Steenbergen Frank van, Yadav, Shobha. Groundwater depletion and quality in the Indo Gangetic Basin mapped from in situ observations. Nature Geosciences. DOI:10.1038/NGEO2791. (2016)

11. MacDonald AM, Bonsor HC, Taylor R, Shamsudduha M, Burgess WG, Ahmed KM, Mukherjee A, Zahid A, Lapworth D, Gopal K, Rao MS, Moench M, Bricker SH, Yadav SK, Satyal Y, Smith L, Dixit A, Bell $R$, van Steenburgen F, Basharat M, Gohar MS, Tucker J, and Maurice L. Groundwater Resources in the Indo-Gangetic basinResilience to climate change and abstraction. British Geological Survey Open Report, OR/15/047, 63pp. (2015).

12. Macdonald, A. M., Bonsor, H. C., Krishan, Gopal, Rao, M. S., Ahmed, K.M., Taylor, R.G., Shamsudduha, M., Steenburgen, F Van, Mackenzie, A.A., Dixit, A, Moench, M, Tucker, J. Groundwater in the Indo Gangetic Basin: Evolution of Groundwater Typologies. In Proc. of 41st International Conf. of International Association of Hydro-geologist (IAH-2014) on Groundwater: Challenges and Strategies during Sep. 18-19, 2014. at Marrakech Morocco. (2014).

13. Macdonald, Alan, Bonsor, Helen, Rao, M. Someshwar, Krishan, Gopal, Steenburgen, Frank Van, Ahmed, Kazi, Shamsudduha, Mohammad, Dixit, Ajaya, Moench, Marcus. Groundwater Topologies In the Indo Gangetic
Basin, In Proc. of International Conf. on Advances in Water Resources Development \& Mangement held at PU, Chandigarh during Oct. 23-27, 2013. P: 2. (2013).

14. Priyanka, Krishan G, Sharma L. M, Yadav B. K, Ghosh N. C. Analysis of Water Level Fluctuations and TDS Variations in the Groundwater at Mewat (Nuh) District, Haryana (India). Current World Environment. 11(2): 388-398. (2016).

15. Rodell, M., I. Velicogna, and J. S. Famiglietti. Satellite-based estimates of groundwater depletion in India. Nature, 460(7258), 9991002. (2009).

16. CGWB, Central Ground Water Board. Ground Water Information Booklet, Haridwar District, Uttarakhand. (2009).

17. Krishan, Gopal, Singh, Surjeet, Khanna, Anurag, Singh, R.P., Ghosh, N.C. Water quality index of groundwater in Haridwar district, Uttarakhand. Water and Energy International. 58 (10): 55-58. (2016).

18. Krishan, Gopal, Singh, R.P., Khanna, Anurag, Singh, Surjeet, Ghosh, N.C. Recent groundwater status of groundwater in Haridwar district, Uttarakhand. In: Proceedings of National Seminar on R \& D Perspective for Rejuvenation of River Ganga during 16-17 December, 2015 at NIH, Roorkee. Pp: 12-13. (2015).

19. Singh Surjeet, Ghosh, N.C., Krishan Gopal, Galkate Ravi, Thomas T. and Jaiswal R.K. Development of an Overall Water Quality Index (OWQI) for Surface Water in Indian Context. Current World Environment. 10(3): 813-822. (2015).

20. http://censusindia.gov.in/

21. APHA. 2012. Standard Methods for the Examination of Water and Wastewater. 22nd Edition. Published by the American Public Health Association, American Water and Waterworks Association and Water Environment Federation. 